Brit. F. Psychiat. (1972), 121, $115-20$

\title{
Correspondence
}

Letters for publication in the Correspondence columns should be addressed to:

The Editor-in-Chief, British Journal of Psychiatry, Chandos House, 2 Queen Anne Street, London, WIM gIS.

\section{CHARTER ADDRESS AND DURKHEIM'S VIEWS ON SUICIDE}

DeAr Sir,

Readers of the Fournal will be glad of the opportunity to study Sir Martin Roth's Charter Address (April, pp. 359-66). One section-the medical model - will no doubt be of particular interest. In this section, Professor Roth refers to Durkheim's Suicide (1897, translated 1952), but rather than draw attention to the valuable discussion of the social factors involved and the question of causality he does, I believe, rather overemphasize the inadequacy of Durkheim's examination of suicide in relation to mental illness (psychopathic states).

Durkheim was concerned to find the factors which accounted for the variations in the suicide rate. He not unreasonably felt he would thus be led to the causes of the phenomenon. He was satisfied that these were social, and his discussion of 'insanity' is based on his belief that it is essentially intrapersonal and extrasocial. He reached the conclusion that 'insanity' and 'neurasthenia' could not account for the variations observed, but he did not try to deny that they played their part at an individual level. It is clear that there are several unsatisfactory things in his discussion of suicide and psychopathic states. He was wrong, for instance, to regard neurasthenia as being merely a less severe form of insanity. This is surprising in one way, in that he had already categorized the different types of suicide occurring in the insane, but understandable in that he was unable to examine the relationship between neurasthenia and suicide directly for lack of available data. He admitted that there must be many more neurasthenics than insane, but he put forward the view that the neurasthenic would merely be more susceptible to the (social) suicidogenic currents than the normal person.

As is to be expected, much of Durkheim's discussion in the latter part of the book centres around the question of causality. In modern terms, the issue revolves in part around the relationship between suicide and depression, but both, not to mention crime, alcoholism and drug dependence, can be usefully seen in terms of Durkheim's thesis (Carstairs, 1962).

We who are used to letting our notions reverberate in computers, and who have tasted the delights of factor analysis, may well find Durkheim's own multivariate analysis of the data available to him rather tedious, and there are certainly many minor points over which he has been proved wrong. His basic thesis, however, still stands, and the results of recent research are by no means incompatible with it.

It was Hume (1777) who first disentangled suicide from 'superstition and false religion' and exposed the bogus nature of the reasoning used to defend the sanctions against it. It was Durkheim who, with his account of Egoistic and Anomic suicides in particular, effectively answered Hume's extreme position 'that suicide may often be consistent with interest and with our duty to ourselves', and provided psychiatrists with a most valuable framework within which to tackle the problem.

Royal Cornhill Hospital,

R. F. Rockstro.

Cornhill Road,

Aberdeen, $A B 9$ 2ZH.

\section{REFERENCEs}

Carstairs, G. M. (1964). This Island Nowo. Penguin (1962 Reith Lectures).

DURKHEm, E. (1897). Suicide: A Study in Sociology (American translation 1952). London: Routledge and Kegal Paul. Hume, D. (1777). Essay: On Suicide.

\section{THE ROYAL COLLEGE OF PSYCHIATRISTS MEMORANDUM ON THE ABORTION ACT IN PRACTICE}

Dear Sir,

I was interested to read the College's 'Memorandum on the Abortion Act in Practice' (Joumal, April 1972), but surprised that there was no mention of psychiatric follow-up.

Whilst the majority of recent papers report favourable results (e.g. Peck and Marcus, 1966; Patt et al., 1969; Whittington, 1970; Senay, 1970), there are undoubtedly some women who react unfavourably to termination of pregnancy.

Nidwander and Patterson (1967) found that only 5 per cent of 161 women who had been aborted suffered regrets, and these were married women aborted for medical reasons. Pare and Raven (1970) noted that psychiatric sequelae were much more common in those patients reluctant to have the 